\title{
PENGEMBANGAN APLIKASI MOBILE "EXAMINATION OF SHARIA" (EXSHAR) SEBAGAI MEDIA EVALUASI LAYANAN LEMBAGA KEUANGAN SYARIAH
}

\author{
Novedi Risanti Langgi, Luqman Hakim \\ Fakultas Ekonomi, Universitas Negeri Surabaya \\ Ketintang, Surabaya, Jawa Timur, 60231 \\ vedirisanti98@gmail.com
}

\section{Article History}

Received: 30 Juni 2020, Accepted: 24 November 2020, Published: 28 Mei 2021

\begin{abstract}
Abstrak
Evaluasi pembelajaran yang dilakukan di sekolah saat ini masih berpaku pada cara-cara konvensional yang tidak lagi relevan terhadap perkembangan zaman. Penelitian ini bermaksud untuk mendeskripsikan pengembangan media evaluasi Examination of Sharia (Exshar). Prosedur penelitian yang diterapkan mengadopsi model pengembangan milik Thiagarajan, yakni Define, Design, Develop, dan Disseminate (4D). Uji coba dilaksanakan secara terbatas. Instrumen pengumpulan data meliputi lembar telaah, lembar validasi, dan angket respon peserta didik. Data yang diperoleh dianalisis menggunakan analisis deskriptif kuantitatif. Hasil akhir dari penelitian ini berupa produk aplikasi mobile berbasis offline. Hasil penelitian menunjukkan bahwa aplikasi Exshar layak digunakan sebagai media evaluasi mata pelajaran Layanan Lembaga Keuangan Syariah. Aplikasi ini membantu tenaga pendidik melaksanakan evaluasi berbasis Higher Order Thinking Skills (HOTS), memudahkan pengoreksian jawaban, dan mengantisipasi terjadinya kesalahan dalam penskoran. Bagi siswa, aplikasi ini memudahkan dan meningkatkan antusias dalam mengerjakan soal.
\end{abstract}

Keyword: Media Evaluasi, Aplikasi Mobile, Sekolah Menengah Kejuruan

\begin{abstract}
The evaluation of learning carried out in schools is still adhering to conventional methods that are no longer relevant to the times. This study emphasizes to describe the development of the Sharia Exam evaluation media. The research procedure applied by Thiagarajan's development model, namely Define, Design, Develop, and Disseminate (4D). The trial was carried out on a limited basis. The data instruments include study sheets, validation sheets, and student response questionnaires. The data obtained were analyzed using quantitative descriptive analysis. The final result of this research is an offline based mobile application product. The results showed that the Exshar application was feasible to use as a medium for evaluating Islamic Financial Institution Services subjects. This application helps educators carry out Higher Order Thinking Skills (HOTS) based evaluations, makes it easy to correct answers, and anticipates errors in scoring. For students, this application makes it easy and increases enthusiasm in doing questions.
\end{abstract}

Keyword: Put 3-5 your keywords here in Bahasa Indonesia; keywords separated by semicolon 


\section{PENDAHULUAN}

Pengembangan media evaluasi berbasis teknologi tengah gencar dilakukan dalam beberapa kurun waktu terakhir. Saat ini tersedia berbagai macam media evaluasi yang dapat diakses melalui komputer maupun smartphone. Berbagai platform kuis online seperti Socrative, Kahoot, dan Plickers dapat dengan mudah diakses oleh guru untuk melakukan evaluasi pembelajaran (Elmahdi, Al-Hattami, \& Fawzi, 2018). Fenomena ini merupakan dampak masuknya era revolusi industri 4.0 dimana teknologi tidak dapat dipisahkan dari kehidupan manusia (Hidayatno, Destyanto, \& Hulu, 2019). Penelitian Jermsittiparsert dan Sriyakul (2020) menunjukkan bahwa mayoritas negara di Asia fokus untuk berinvestasi pada kegiatan penelitian dan pengembangan untuk meningkatkan kualitas pendidikan mereka. Begitu pula di Indonesia, pemerintah sedikit demi sedikit memperbaiki sistem pendidikan yang ada. Salah satunya dengan menggeser instrumen ujian nasional berbasis kertas (paper based test) menjadi ujian nasional berbasis komputer (computer based test). Hal ini merupakan salah satu upaya pemerintah untuk menyelaraskan pendidikan dengan perkembangan teknologi (Carolina, 2017).

Akan tetapi kenyataan di lapangan menunjukkan bahwa terdapat banyak sekolah yang masih menggunakan media kertas pada kegiatan evaluasi sehari-hari (paper based test) (Iqbal, 2017; Pamungkas \& Hakim, 2019; Yasa, Suastika, \& Zubaidah, 2020). Berdasarkan hasil studi pendahuluan di SMKN 2 Kota Mojokerto melalui wawancara dengan guru Layanan Lembaga Keuangan Syariah, ditemukan fakta bahwa meskipun terdapat fasilitas seperti wifi dan laboratorium komputer namun penggunaannya sangat terbatas. Hal ini disebabkan fasilitas wifi tidak dapat menjangkau seluruh ruangan dan laboratorium komputer digunakan dengan kelas dan jurusan lain secara bergiliran sehingga jarang sekali dalam keadaan kosong. Sehingga sekolah terpaksa menerapkan metode konvensional dalam kegiatan evaluasi sehari-hari.

Namun penelitian lain menunjukkan bahwa meskipun terdapat fasilitas yang memadahi, sekolah lebih memilih menggunakan evaluasi bebasis konvensional (Purwati \& Nugroho, 2018). Sedangkan evaluasi berbasis konvensional sendiri dinilai tidak lagi efektif untuk digunakan karena memiliki banyak kelemahan (Badi'ah, 2014; Dewi dkk., 2018; Pratiwi \& Susanti, 2016; Ramdani dkk., 2019). Penelitian sebelumnya menemukan fakta bahwa evaluasi konvensional membuka peluang bagi peserta didik untuk melakukan kecurangan (Pratama, 2019; Rolisca \& Achadiyah, 2014). Evaluasi konvensional juga dinilai boros waktu dan biaya (Purwati \& Nugroho, 2018). Dari segi biaya, evaluasi konvensional lebih mahal karena masih mengandalkan alat tulis seperti kertas dan tinta untuk mencetak soal ujian. Sedangkan dari segi waktu, evaluasi konvensional membutuhkan waktu yang lebih lama karena pengoreksian lembar jawaban dilakukan secara manual.

Meskipun telah banyak penelitian yang mengembangkan media evaluasi, namun berdasarkan pengetahuan penulis hingga saat ini belum terdapat penelitian yang mengembangkan media evaluasi berwujud aplikasi mobile berbasis offline. Khususnya untuk mata pelajaran Layanan Lembaga Keuangan Syariah. Layanan Lembaga Keuangan Syariah sendiri merupakan mata pelajaran baru hasil implementasi Kurikulum 2013 Revisi. Sehingga belum banyak tersedia perangkat pembelajaran untuk mata pelajaran tersebut, baik bahan ajar maupun media pembelajaran. Penelitian sebelumnya yang serupa dengan penelitian ini lebih banyak berfokus pada pengembangan media evaluasi berbasis komputer (computer based test) (Ayuningtyas, Praherdhiono, \& Wedi, 2018; Rolisca \& Achadiyah, 2014). Walaupun terdapat penelitian yang mengembangkan media evaluasi berbasis aplikasi android (Anggraini \& Saino, 2019; Putri \& Dwijayanti, 2020; Setiawan \& Kusumawijaya, 2019), namun media tersebut dikembangkan untuk mata pelajaran lain dan hanya dapat diakses apabila tersedia koneksi internet saja (online).

Berdasarkan paparan di atas, peneliti tertarik untuk melakukan pengembangan media evaluasi berwujud aplikasi mobile berbasis offline. Tujuan penelitian ini adalah mengembangkan media evaluasi yang praktis, fleksibel, mudah dioperasikan, dan dapat digunakan dalam kondisi apapun, baik terdapat 
koneksi internet maupun tidak. Aplikasi mobile dipilih untuk mengembangkan media evaluasi ini karena memiliki beragam kelebihan. Aplikasi mobile sendiri merupakan perangkat lunak yang dirancang untuk dioperasikan pada smartphone, tablet, atau perangkat seluler lainnya (Zein, Salleh, dan Grundy, 2016). Saat ini smartphone hampir dimiliki oleh setiap orang tak terkecuali guru dan peserta didik. Penelitian terbaru menunjukkan bahwa smartphone menjadi media yang paling sering digunakan pada proses pembelajaran mengalahkan media-media lain seperti komputer, laptop, tablet, televisi, dan kamera digital (Rihtarsic \& Avsec, 2019).

Penelitian ini disusun menggunakan model 4D yang dipopulerkan oleh Thiagarajan, Semmel, dan Semmel. Model tersebut terdiri dari 4 tahap yakni Define (Pendefinisian), Design (Perancangan), Develop (Pengembangan), dan Disseminate (Penyebaran). Hasil akhir dari penelitian ini adalah aplikasi mobile Examination of Sharia (Exshar) berbasis offline sebagai media evaluasi mata pelajaran Layanan Lembaga Keuangan Syariah kelas XI Semester 1. Produk yang dikembangkan akan melalui uji validasi ahli materi, ahli evaluasi, dan ahli media. Produk yang dinyatakan lolos, selanjutnya akan diuji cobakan secara terbatas kepada 20 peserta didik Kelas XI SMKN 2 Kota Mojokerto. Produk ini diharapkan mampu menjadi solusi bagi sekolah yang tdak memiliki fasilitas yang mendukung untuk melaksanakan evaluasi berbasis teknologi..

\section{METODE}

Penelitian ini tergolong kedalam jenis penelitian pengembangan (Research and Development). Prosedur penelitian mengacu pada model pengembangan Thiagarajan, Semmel, dan Semmel. Model pengembangan ini dipilih karena cocok digunakan untuk mengembangkan suatu perangkat pembelajaran. Dalam penelitian ini perangkat yang dikembangkan adalah media evaluasi berbasis aplikasi mobile. Tahapan dalam model pengembangan ini tersusun secara sistematis dan terperinci. (Gunawan, Sutrisno, \& Muslim, 2020). Tahapannya cukup ringkas tetapi telah mencakup keseluruhan dari prosedur pengembangan produk.

Terdapat empat tahap dalam model pengembangan Thiagarajan, Semmel, dan Semmel yang selanjutnya disingkat 4D. Tahapan tersebut yaitu Define (Pendefinisian), Design (Perancangan), Develop (Pengembangan), dan Disseminate (Penyebaran). Dalam penelitian ini tahap Disseminate tidak dilaksanakan karena adanya keterbatasan waktu dan biaya sehingga peneliti membatasi prosedur pengembangan hanya sampai pada tahap Develop saja.

Selanjutnya penelitian ini diawali dari tahap Define (Pendefinisian) yang berfungsi untuk mengidentifikasi permasalahan pokok yang dialami sekolah dan apa saja yang dibutuhkan untuk mengatasi permasalahan tersebut. Tahap ini dapat disebut juga dengan tahap analisis kebutuhan. Permasalahan dalam penelitian ini adalah masih maraknya penggunaan metode konvensional dalam evaluasi yang dirasa tidak efisien dan memiliki banyak kelemahan. Selanjutnya tahap Design (Perancangan). Setelah menemukan solusi atas permasalahan yang dihadapi, peneliti dapat membuat rancangan awal produk. Dalam penelitian ini peneliti mengembangkan aplikasi mobile berbasis offline sebagai media evaluasi dengan pendekatan soal Higher Order Thinking Skills (HOTS) pada mata pelajaran Layanan Keuangan Lembaga Syariah kelas XI Semester 1. Selanjutnya tahap Develop (Pengembangan) terbagi menjadi dua langkah utama yakni expert appraisal (penilaian atau validasi ahli) dan developmental testing (uji coba produk).

Subjek penelitian ini adalah peserta didik kelas XI Jurusan Perbankan Syariah SMKN 2 Kota Mojokerto. Teknik pengumpulan data terdiri dari wawancara dan angket. Wawancara dilakukan dengan guru Layanan Lembaga Keuangan Syariah untuk mengetahui sistem evaluasi yang diterapkan di sekolah. Angket akan disebar kepada validator ahli serta peserta didik guna mengetahui kelayakan media evaluasi. Instrumen penelitian yang digunakan berupa lembar telaah, lembar validasi, dan angket respon peserta didik. Data yang diperoleh akan di analisis dengan cara deskriptif kuantitatif. Untuk mengukur 
kelayakan media evaluasi, peneliti menggunakan kriteria kelayakan milik Riduwan (2015) seperti pada tabel 1 berikut.

Tabel 1. Kriteria Tingkat Kevalidan (Riduwan, 2015)

\begin{tabular}{|c|c|}
\hline Persentase & Interpretasi \\
\hline $81 \%-100 \%$ & Sangat Layak \\
\hline $61 \%-80 \%$ & Layak \\
\hline $41 \%-60 \%$ & Cukup \\
\hline $21 \%-40 \%$ & Tidak Layak \\
\hline $0 \%-20 \%$ & Sangat Tidak Layak \\
\hline
\end{tabular}

Uji coba dilakukan secara daring dikarenakan kondisi yang belum mendukung akibat pandemi Covid 19. Sampel dalam penelitian ini berjumlah 20 peserta didik. Peneliti mengirimkan aplikasi Exshar ke grup whatsapp yang kemudian didownload dan diinstal oleh peserta didik di smartphone masing-masing. Selanjutnya peserta didik mengerjakan soal Ulangan Harian 1 secara serempak dari rumah dengan waktu yang telah ditentukan sebelumnya. Pengisian angket respon oleh peserta didik dilakukan secara online melalui google form.

\section{HASIL}

Hasil penelitian akan disajikan tahap demi tahap dari model pengembangan 4D. Untuk lebih lengkapnya sebagai berikut.

\section{Tahap Define (Pendefinisian)}

Tahap define menghasilkan temuan permasalahan pokok yang dialami oleh sekolah. Permasalahan tersebut adalah masih digunakannya media berbasis konvensional dalam melaksanakan evaluasi pembelajaran. Hal ini dilatar belakangi oleh kondisi fasilitas sekolah yang tidak mendukung seperti wifi yang hanya menjangkau ruangan tertentu dan laboratorium yang jumlahnya terbatas. Berdasarkan permasalahan tersebut ditemukan solusi yakni pengembangan media evaluasi aplikasi mobile berbasis offline.

\section{Tahap Design (Perancangan)}

Pada tahap ini dihasilkan rancangan awal/prototype media evaluasi Exshar. Media evaluasi Exshar dikembangkan untuk dapat digunakan selama satu semester. Soal disusun menggunakan pedekatan soal HOTS. Materi soal meliputi konsep dasar Layanan Lembaga Keuangan Syariah, sumber dana bank syariah, penghimpunan dana bank syariah, pembiayaan pada bank syariah, bagi hasil dan bonus pada produk penghimpunan dana bank syariah, bagi hasil dan margin pada produk pembiayaan bank syariah, serta pembelian dan penjualan Surat Berharga Pasar Uang (SBPU), Sertifikat Wadiah Bank Indonesia (SWBI), dan valuta asing pada akad sharf. Jumlah keseluruhan soal yang terdapat di dalamnya adalah 210 soal yang terdiri dari 30 soal Ulangan Harian 1, 30 soal Ulangan Harian 2, 40 soal Ujian Tengah Semester, 30 soal Ulangan Harian 3, 30 soal Ulangan Harian 4, dan 50 soal Ujian Akhir Semester. Media evaluasi ini dilengkapi dengan fitur pewaktu otomatis sehingga apabila waktu telah habis ujian akan berakhir dengan sendirinya. Fitur lainnya yakni penskoran otomatis dan pratinjau. Fitur pratinjau berfungsi untuk mengetahui nomor soal mana saja yang telah terjawab dan nomor soal mana saja yang belum terjawab.

\section{Tahap Develop (Pengembangan)}

Tahap ini menghasilkan produk jadi media evaluasi Exshar. Produk yang berhasil dikembangkan kemudian ditelaah oleh para ahli yang terdiri dari ahli materi, ahli evaluasi, dan ahli media. Penelaahan tersebut menghasilkan komentar, saran, serta masukan terhadap prototype produk yang dikembangkan. Telaah ahli materi menghasilkan beberapa perbaikan diantaranya pada soal yang level kognitifnya lemah sehingga kurang memenuhi standar HOTS, penulisan nominal Rupiah yang belum terdapat dua digit koma dibelakangnya, dan kisi-kisi soal yang belum tersedia. Sedangkan telaah ahli evaluasi menghasilkan adanya soal yang tidak layak dan tidak memenuhi aspek evaluasi. Soal yang tidak layak kemudian dibuang dan diganti dengan soal baru. Telaah ahli media menghasilkan perbaikan pada tampilan media diantaranya komposisi huruf yang kurang besar dan komposisi warna yang kurang terang.

Selanjutnya hasil uji validasi produk memperoleh presentase ahli materi $91 \%$ kategori sangat layak dengan rincian 2 pertanyaan memperoleh skor 10, 7 pertanyaan memperoleh skor 9 , dan 1 pertanyaan memperoleh skor 8. Skor tersebut merupakan gabungan skor dari validator ahli materi 1 (dosen) dan validator ahli materi 2 (guru). Selanjutnya hasil uji validasi ahli evaluasi memperoleh presentase 90,59\% kategori sangat layak dengan rincian 9 
pertanyaan memperoleh skor 5 dan 8 pertanyaan memperoleh skor 4 . Kemudian hasil uji validasi ahli media memperoleh presentase 96,92\% kategori sangat layak dengan rincian 11 pertanyaan memperoleh skor 5 dan 2 pertanyaan memperoleh skor 4. Rekapitulasi hasil uji validasi media evaluasi Exshar disajikan pada tabel 2 berikut.

Tabel 2. Rekapitulasi Hasil Validasi Media Evaluasi Exshar

\begin{tabular}{|c|l|c|c|}
\hline No. & \multicolumn{1}{|c|}{ Komponen } & Persentase & Kriteria \\
\hline 1 & Materi & $91 \%$ & Sangat Layak \\
\hline 2 & Evaluasi & $90,59 \%$ & Sangat Layak \\
\hline 3 & Media & $96,92 \%$ & Sangat Layak \\
\hline
\end{tabular}

Sementara itu pengisian angket respon oleh 20 peserta didik menghasilkan presentase 96,92\% dengan predikat sangat baik. Terdapat 13 pertanyaan dalam angket tersebut dengan rincian 6 pertanyaan mendapatkan satu jawaban Tidak, 1 pertanyaan mendapatkan dua jawaban Tidak, dan 6 pertanyaan mendapatkan keseluruhan jawaban Ya. Adapula saran dari peserta didik adalah huruf yang digunakan dalam aplikasi diperbesar dan tampilan gambar atau animasi diperjelas. Hasil angket respon peserta didik secara rinci disajikan pada gambar berikut.

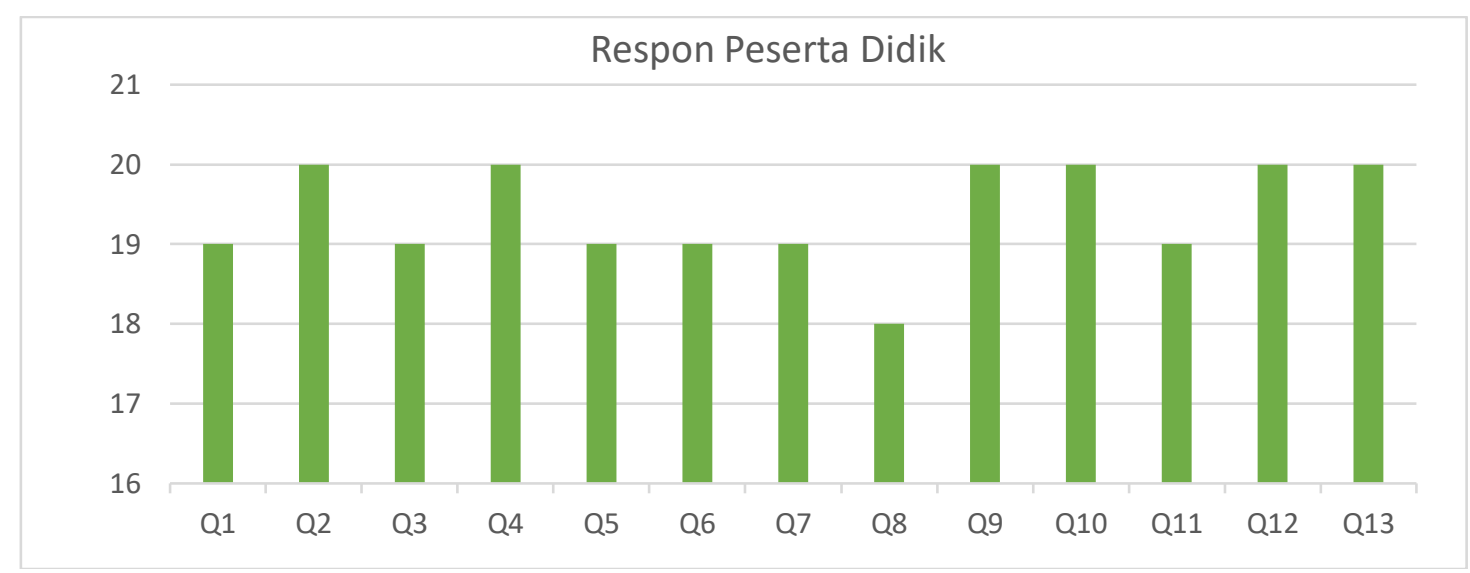

Gambar 1. Hasil Respon Peserta Didik

\section{PEMBAHASAN}

Saat ini penggunaan aplikasi mobile telah meningkat secara global dibandingkan aplikasi desktop. Kemudahan, kepraktisan, kemenarikan tampilan, serta biaya yang terjangkau dalam mengaksesnya menjadi faktor utama kepopuleran aplikasi mobile (Kumar \& Mohite, 2018). Bahkan banyak aplikasi dapat diunduh secara gratis oleh pengguna smartphone melalui platform play store ataupun app store. Aplikasi mobile pada mulanya dikembangkan untuk fungsionalitas yang terbatas seperti permainan, kalkulator, dan web browser (Wongso, 2018). Namun seiring berkembangnya waktu kebutuhan masyarakat terhadap aplikasi mobile semakin kompleks. Kebutuhan tersebut diantaranya adalah untuk menjalankan pekerjaan ataupun membangun relasi sosial (Yuawanto, 2016). Sehingga para developer mulai mengembangkan beragam aplikasi mobile untuk berbagai sektor. Mulai dari sektor kesehatan, pemerintahan, keamanan, bisnis, dan pendidikan.

Dalam sektor pendidikan, aplikasi mobile umumnya digunakan sebagai media pembelajaran. Namun pada penelitian ini peneliti mencoba mengembangkan aplikasi mobile sebagai media evaluasi. Penggunaan media dalam pembelajaran sudah selayaknya tidak hanya terbatas sebagai perantara penyampai materi pembelajaran, namun juga dapat menjadi alat ukur hasil belajar peserta didik (Hakim, Wedi, \& Praherdhiono, 2020). Penelitian ini dilatar belakangi oleh penggunaan metode evaluasi konvensional yang kurang menarik minat peserta didik. Selain itu pembelajaran pada abad ini telah beralih pada pembelajaran yang modern (Indahini, Sulton, \& Husna, 2018), sehingga penerapan metode evaluasi konvensional dirasa tidak lagi relevan terhadap perkembangan zaman.

Penelitian ini mengadopsi model pengembangan yang dipopulerkan oleh Thiagarajan, Semmel, dan Semmel. Model pengembangan tersebut terdiri dari 4 tahap yakni tahap Define, Design, Develop, dan Disseminate yang kemudian disebut dengan model pengembangan 4D. Model pengembangan ini dipilih karena sesuai untuk diterapkan dalam pengembangan suatu perangkat pembelajaran. Salain itu model pengembangan ini langkahlangkahnya cukup ringkas dan simpel tetapi sudah mewakili inti dari metode pengembangan suatu produk. Namun dalam penelitian ini peneliti hanya mengimplemantasikan langkah-langkah 4D hingga tahap Develop saja. Hal ini 
dikarenakan adanya keterbatasan waktu dan biaya yang dimiliki peneliti untuk melakukan tahap Disseminate. Produk akhir dari penelitian ini berupa media evaluasi Examination of Sharia (Exshar) berbasis aplikasi mobile offline.

Higher Order Thinking Skills (HOTS) atau kemampuan berpikir tingkat tinggi merupakan keterampilan yang dibutuhkan pada abad 21. Data menunjukkan bahwa peringkat Indonesia dalam Programme for International Student Assessment (PISA) dan Trends in International Mathematics and Science Study (TIMSS) tergolong rendah jika dibandingkan dengan negara lain (Direktorat Jenderal Guru dan Tenaga Kependidikan, 2018). Oleh karena itu peningkatan soal evaluasi ke ranah HOTS diharapkan mampu membenahi ketertinggalan tersebut. Pada mulanya pemerintah hanya menerapkan butir soal berbasis HOTS pada skala Ujian Nasional saja. Namun berdasarkan Standar Penilaian pada Kebijakan Kurikulum 2013 sekolah dianjurkan agar menyusun soal evaluasi dengan derajat butir soal HOTS. Soal yang disusun oleh peneliti dalam media evaluasi Exshar sendiri sudah berbasis HOTS. Adapula ranah kognitif soal HOTS untuk tingkat SMK pada taknosomi Bloom yang disempurnakan oleh Anderson dan Krathwohl mencakup ranah C4 (Menganalisis), C5 (Mengevaluasi), dan C6 (Mencipta) (Yani (2019). Untuk mengetahui kualitas soal yang disusun, butir soal dianalisis secara kualitatif oleh penelaah ahli yang terdiri dari ahli materi (isi/content) dan ahli evaluasi (konstruksi dan bahasa). Sedangkan untuk analisis kuantitatif yang mencakup reliabilitas, daya beda, dan tingkat kesukaran soal belum dapat dilaksanakan sehubungan dengan kondisi pandemi Covid 19 yang membuat peneliti tidak dapat melakukan penelitian lebih lanjut di sekolah.

Merujuk pada hasil uji validasi para ahli, media evaluasi Exshar memperoleh presentase uji validasi ahli materi sebesar 91\% dengan kategori sangat layak. Hal ini menunjukkan bahwa media evaluasi Exshar telah memenuhi aspek kesesuaian soal dengan kompetensi dasar, indikator, jenjang sekolah, dan tingkat kelas. Media evaluasi Exshar juga telah memenuhi unsur kelengkapan materi dan keterkinian soal. Selanjutnya hasil uji validasi ahli evaluasi memperoleh presentase sebesar 90,59\% dengan kategori sangat layak. Hal ini menunjukkan bahwa media evaluasi Exshar telah memenuhi aspek konstruksi yang meliputi kejelasan rumusan pokok soal, tidak menggunakan pernyataan negatif ganda, panjang rumusan jawaban yang relatif sama, butir soal tidak bergantung pada jawaban soal sebelumnya, serta kejelasan dan keberfungsian gambar/grafik/diagram. Kemudian aspek HOTS yang meliputi stimulus soal yang menarik dan kontekstual, soal mampu mengukur level kognitif penalaran, dan jawaban yang tersirat pada stimulus. Serta aspek bahasa yakni memenuhi unsur bahasa yang baik dan benar sesuai Pedoman Umum Ejaan Bahasa Indonesia (PUEBI). Adapula hasil uji validasi ahli media memperoleh presentase sebesar 96,92\% dengan kategori sangat layak. Hal ini menunjukkan bahwa media evaluasi Exshar telah memenuhi aspek tampilan media yang baik serta aspek kemudahan penggunaan. Arsyad (2016) menjelaskan kriteria media yang baik adalah sesuai dengan tujuan pembelajaran, praktis, dan dapat mendukung proses pembelajaran dengan baik.

Selanjutnya angket respon peserta didik memperoleh presentase sebesar 96,92\% dengan kategori sangat baik. Hal ini menunjukkan bahwa media evaluasi Exshar mendapatkan respon yang positif dari peserta didik. Peserta didik menilai media evaluasi Exshar membuat mereka lebih antusias dalam mengerjakan soal karena merupakan suatu variasi baru dalam kegiatan evaluasi. Media evaluasi Exshar juga praktis dan mudah dioperasikan. Peserta didik tidak perlu lagi bersusah payah menyiapkan kertas dan alat tulis serta mengisi lembar jawaban. Hal inilah yang meningkatkan minat peserta didik untuk menggunakan media evaluasi Exshar.

Setiap sistem yang dikembangkan pasti memiliki kelebihan dan kekurangan (Mustaqim dan Kurniawan, 2017). Hal ini juga berlaku pada media evaluasi Exshar. Kelebihan dari media evaluasi Exshar diantaranya adalah kepraktisan, fleksibilitas, kemudahan penggunaan, serta efisiensi waktu dan biaya. Selain itu media evaluasi Exshar berbasis offline sehingga sekolah yang tidak memiliki jaringan wifi tetap dapat menggunakannya. Menurut Mitra dan Srivastava (2020) aplikasi berbasis offline dinilai memiliki kinerja yang lebih baik, minim mengalami gangguan, dan membutuhkan waktu yang lebih singkat untuk mengakses informasi. Hal ini karena aplikasi offline tidak bergantung pada sinyal jaringan internet. Keunggulan lainnya adalah media evaluasi Exshar dapat melakukan pengoreksian jawaban dan penskoran secara otomatis. Sehingga guru tidak perlu repot mengoreksi jawaban peserta didik satu per satu dan juga menghindari adanya kesalahan pengoreksian jawaban diakibatkan human error. Selain itu di era pandemi Covid 19 saat ini sangat tidak memungkinkan bagi sekolah untuk mengadakan evaluasi pembelajaran secara langsung atau tatap muka. Penggunaan media evaluasi Exshar dapat menjadi salah satu solusi untuk mengatasi persoalan tersebut. 
Adapula kekurangan dari media evaluasi Exshar adalah aplikasi ini hanya dapat dijalankan pada smartphone yang menggunakan sistem operasi android. Dibanding windows dan iOS, android sendiri merupakan sistem operasi yang paling populer di dunia dengan pangsa pasar lebih dari 80\% (Kunda \& Chishimba, 2018). Survey yang peneliti lakukan saat studi pendahuluan menunjukkan bahwa smartphone yang dimiliki peserta didik hampir secara keseluruhan berjenis android. Hal inilah yang kemudian menjadi pertimbangan peneliti memilih platform android untuk mengembangkan media evaluasi Exshar. Namun, hal itu sejalan dengan penelitian sebelumnya yang dilakukan oleh (Surahman \& Alfindasari, 2017), bahwa secara umum pengguna smartphone mayoritas berbasis Android.

Penelitian pengembangan mobile learning saat ini lebih banyak berkembang kepada penelitian yang terpersonalisasi kepada pengguna. Istilah lain yang menjelaskan konsep tersebut adalah adaptive mobile learning (Surahman \& Surjono, 2017). Sistem mobile learning dapat menggunakan data pengguna dalam memberikan keputusan. Artinya pengambilan keputusan didasarkan pada karakteristik dari pengguna itu sendiri. Hal ini menarik untuk dikembangkan pada penelitian di masa depan.

\section{SIMPULAN}

Berdasarkan uraian yang telah dipaparkan, dapat ditarik kesimpulan bahwa aplikasi mobile Examination of Sharia (Exshar) layak dikembangkan sebagai media evaluasi mata pelajaran Layanan Lembaga Keuangan Syariah. Ditinjau dari hasil uji validasi para ahli, aplikasi ini mendapatkan kategori sangat layak dari ahli materi, ahli evaluasi, dan ahli bahasa. . Selanjutnya ditinjau dari hasil uji coba, aplikasi ini mendapatkan respon yang sangat positif dari peserta didik. Seluruh peserta didik sepakat bahwa penggunaan aplikasi ini memudahkan mereka melakukan kegiatan evaluasi,meningkatkan antusiasme dalam mengerjakan soal, dan meningkatkan kemampuan berpikir tingkat tinggi melalui soal berstandar HOTS. Sedangkan para guru merasa sangat terbantu dengan adanya fitur pengoreksian jawaban dan penskoran secara otomatis. Penelitian ini masih memerlukan validitas soal lebih lanjut dalam bentuk kuantitatif melalui perhitungan reliabilitas, daya beda, dan tingkat kesukaran soal. Diharapkan penelitian selanjutnya dapat meneliti mengenai validitas media evaluasi Exshar.

\section{DAFTAR RUJUKAN}

Anggraini, E. P., \& Saino. (2019). Pengembangan Alat Evaluasi Pembelajaran Berbasis Software Contruct 2 pada Kompetensi Dasar Menganalisis Kesehatan dan Keselamatan Kerja dalam Pengelolaan Bisnis Ritel Kelas XI Bisnis Daring dan Pemasaran di SMK Negeri 4 Surabaya. Jurnal Pendidikan Tata Niaga, 7(3).

Arsyad, A. (2016). Media Pembelajaran (19th ed.). Jakarta: RajaGrafindo Persada.

Ayuningtyas, D., Praherdhiono, H., \& Wedi, A. (2018). Aplikasi Web Evaluasi Proses Pembelajaran dengan Pendekatan Assessmen As Learning. Jurnal Kajian Teknologi Pendidikan, 1(1).

Badi'ah, N. 'Ainul. (2014). Pengembangan Media Evaluasi Belajar Ilmu Pengetahuan Alam Berbasis Web Offline (Pada Pokok Bahasan Mahluk Hidup dan Proses Kehidupan) Berdasarkan SKL 2013 di Madrasah Ibtidaiyah Imami Kepanjen Malang. UIN Maulana Malik Ibrahim Malang.

Carolina, E. S. (2017). Are Islamic Boarding Schools Ready The Use of the Computer-Based Test in the National Exam Policy for English Subject. Journal of Islamic Education, 22.

Dewi, C. K., Rakhmawati, R., \& Mujib, M. (2018). Pengembangan Alat Evaluasi Menggunakan Aplikasi Kahoot pada Pembelajaran Matematika Kelas X. Indonesian Journal of Science and Mathematics Education, 1(2).

Direktorat Jenderal Guru dan Tenaga Kependidikan. (2018). Buku Pegangan Pembelajaran Berorientasi pada Keterampilan Berpikir Tingkat Tinggi.

Elmahdi, I., Al-Hattami, A., \& Fawzi, H. (2018). Using Technology for Formative Assessment to Improve Students Learning. TOJET: The Turkish Online Journal of Educational Technology, 17. 
Gunawan, D., Sutrisno, \& Muslim. (2020). Pengembangan Perangkat Pembelajaran Matematika Berdasarkan TPACK untuk Meningkatkan Kemampuan Berpikir Kritis. Jurnal Pendidikan Matematika, 11.

Hakim, L. N., Wedi, A., \& Praherdhiono, H. (2020). Electronic Module (E-Module) Untuk Memfasilitasi Siswa Belajar Materi Cahaya dan Alat Optik di Rumah. Jurnal Kajian Teknologi Pendidikan, 3(3).

Hidayatno, A., Destyanto, A. R., \& Hulu, C. A. (2019). Industry 4.0 Technology Implementation Impact to Industrial Sustainable Energy in Indonesia: A Model Conceptualization. Energy Procedia, 156.

Indahini, R. S., Sulton, \& Husna, A. (2018). Pengembangan Multimedia Mobile Learning pada Mata Pelajaran Simulasi dan Komunikasi Digital Kelas X SMK. Jurnal Kajian Teknologi Pendidikan, $1(2)$.

Iqbal, W. M. G. (2017). Pengembangan Alat Evaluasi Berbasis Wondershare Quiz Creator Pada Materi Koloid Kelas XI Di SMA Koperasi Pontianak. Universitas Muhammadiyah Pontianak.

Jermsittiparsert, K., \& Sriyakul, T. (2020). Determinants of Quality Education in Asian Countries Impact of Social Globalization, Happiness and Research and Development. Journal of Security And Sustainability Issues, 9.

Kumar, B. A., \& Mohite, P. (2018). Usability of Mobile Learning Applications: A Systematic Literature Review. Journal Computer Education, 5.

Kunda, D., \& Chishimba, M. (2018). A Survey of Android Mobile Phone Authentication Schemes. Mobile Networks and Applications Journal.

Mitra, P., \& Srivastava, G. (2020). Enterprise Applications Reimagined-Cloud abridges mistery of Mobile Offline Working. Procedia Computer Science, 171.

Mustaqim, I., \& Kurniawan, N. (2017). Pengembangan Media Pembelajaran Berbasis Augmented Reality. Jurnal Edukasi Elektro, 1.

Pamungkas, N. T. S., \& Hakim, L. (2019). Pengembangan Alat Evaluasi Berbasis Computer Based Test (CBT) pada Materi Jurnal Penyesuaian Perusahaan Dagang di SMA Negeri 1 Puri Mojokerto. Jurnal Pendidikan Akuntansi, 7(1).

Pratama, F. D. (2019). Aplikasi Ulangan Harian Online Menggunakan Metode Linear Congruential Generator Berbasis Website. Universitas Teknologi Yogyakarta.

Pratiwi, V., \& Susanti. (2016). Pengembangan Alat Evaluasi Pembelajaran Berbasis ICT Menggunakan Wondershare Quiz Creator pada Materi Penyusutan Aset Tetap. Jurnal Pendidikan, 4(1).

Purwati, D., \& Nugroho, A. N. P. (2018). Pengembangan Media Evaluasi Pembelajaran Sejarah Berbasis Google Formulir di SMAN 1 Prambanan. Istoria Jurnal Pendidikan Dan Sejarah, 4(1).

Putri, Y. D., \& Dwijayanti, R. (2020). Pengembangan Alat Evaluasi Berbantuan Aplikasi Android pada Mata Pelajaran Penataan Produk Kelas XI BDP di SMKN 10 Surabaya. Jurnal Pendidikan Tata Niaga, 9(1).

Ramdani, A., Jufri, A. W., Gunawan, Saputra, S. H., \& Zulkifli, L. (2019). Pengembangan Alat Evaluasi Pembelajaran IPA yang Mendukung Keterampilan Abad 21. Jurnal Penelitian Pendidikan IPA, $5(1)$.

Riduwan. (2015). Dasar-Dasar Statistika. Bandung: Alfabeta.

Rihtarsic, D., \& Avsec, S. (2019). Mobile Technology in A Strategy to Enchance Entrepreneural Learning: A Dreamy M-Learning Erasmus + Project Case Study. World Transactions on Engineering and Technology Education Journal, 7. 
Rolisca, R. U. C., \& Achadiyah, B. N. (2014). Pengembangan Media Evaluasi Pembelajaran Dalam Bentuk Online Berbasis E-Learning Menggunakan Software Wondershare Quiz Creator Mata Pelajaran Akuntansi SMA Brawijaya Smart School (BSS). Jurnal Pendidikan Akuntansi Indonesia, XII(1), 41-48.

Setiawan, V., \& Kusumawijaya, R. I. (2019). Pengembangan Media Evaluasi Pembelajaran Sejarah Berbasis Android di Kelas X SMK Penerbangan AAG Adisutjipto. Istoria Jurnal Pendidikan Dan Sejarah, 15(1).

Surahman, E., \& Surjono, H. D. (2017). Pengembangan adaptive mobile learning pada mata pelajaran biologi SMA sebagai upaya mendukung proses blended learning. Jurnal Inovasi Teknologi Pendidikan, 4(1), 26-37.

Surahman, E., \& Alfindasari, D. (2017, September). Developing adaptive mobile learning with the principle of coherence Mayer on biology subjects of high school to support the open and distance education. In 3rd International Conference on Education and Training (ICET 2017) (pp. 184-190). Atlantis Press.

Wongso, V. O. H. (2018). Pengenalan Mobile. Retrieved October 26, 2020, from Binus University School of Information Systems website: https://sis.binus.ac.id/2018/02/13/pengenalan-mobile/

Yani, A. (2019). Cara Mudah Menulis Soal HOTS (1st ed.). Bandung: PT Refika Aditama.

Yasa, A. D., Suastika, K., \& Zubaidah, R. S. A. N. (2020). Pengembangan E-Evaluation Berbasis Aplikasi Hot Potatoes Untuk Siswa Kelas V Sekolah Dasar. Jurnal Ilmiah Sekolah Dasar, 4(1).

Yuawanto, L. (2016). Tinjauan Psikologis Kemanfaatan Sistem Operasi Android. Retrieved October 26, 2020, from UBAYA Universitas Surabaya website: http://www.ubaya.ac.id/2018/content/articles_detail/204/Psychological-Benefit-Overview-ofAndroid-Operating-System.html

Zein, S., Salleh, N., \& Grundy, J. (2016). A Systematic Mapping Study of Mobile Application Terting Technique. Journal of System and Software, 117. 